\title{
Effect and Effectivity of Granular Organic Fertilizer on Growth and Yield of Lowland Rice
}

\author{
Rohmad Budiono ${ }^{1, *}$, Fuad Nur Aziz ${ }^{1}$, Endang Dwi Purbajanti² ${ }^{2}$ Tsitsino Turkadze ${ }^{3}$, \\ and Praptiningsih Gamawati Adinurani ${ }^{4}$

\begin{abstract}
${ }^{1}$ Assesment Institute for Agricultural Technology, Jl. Raya Karangploso Km. 4, Karang Ploso, Malang 65152, East Java, Indonesia

${ }^{2}$ Department of Agriculture, Diponegoro University, Jl. Prof. Sudarto No.13, Tembalang, Semarang 50275, Central Java, Indonesia

${ }^{3}$ Department of Chemical and Environmental Technologies, Akaki Tsereteli State University, 59 Tamar mepe str. Kutaisi 4600, Georgia, UAE

${ }^{4}$ Department of Agrotechnology, Merdeka University of Madiun, Jl. Serayu No.79,

Madiun 63133, East Java, Indonesia
\end{abstract}

\begin{abstract}
The tendency to use inorganic fertilizers in very high doses has causesvarious negative impacts, namely damage to ecosystems, loss of soil fertility to health problems. Therefore, the use of organic fertilizers is encouraged to overcome these problems. The purpose of this study was to determine the effectiveness of Granules Organic Fertilizer (GOF) on the growth and yield of rice plants. The design used was a Randomized Block Design (RBD) with three replications and eight treatments. The GOF treatment was arranged in six levels: $1000 \mathrm{~kg} \mathrm{ha}^{-1}$ to $6000 \mathrm{~kg} \mathrm{ha}^{-1}$, combined with Urea $300 \mathrm{~kg} \mathrm{ha}^{-1}$ and Phonska $300 \mathrm{~kg} \mathrm{ha}^{-1}$, one standard fertilization treatment (Petroganic $2000 \mathrm{~kg} \mathrm{ha}^{-1}+$ Urea $300 \mathrm{~kg} \mathrm{ha}^{-1}$ and Phonska $300 \mathrm{~kg} \mathrm{ha}^{-1}$ ) and one treatment without fertilization as a control. The results showed that GOF had a significant effect on the growth and yield of rice plants. The use of GOF $3000 \mathrm{~kg}+300 \mathrm{~kg}$ Urea $+300 \mathrm{~kg}$ Phonska gave the highest grain yield of $7.21 \mathrm{t} \mathrm{ha}^{-1}$ with $\mathrm{RAE}$ value of $116 \%$ or an increase of $7.45 \%$, and with an $\mathrm{R} / \mathrm{C}$ ratio of 1.4 .
\end{abstract}

Key words: Balance fertilizer, fertilizer efficiency, food security, slow realese fertilizer, soil fertility

\section{Introduction}

Nowadays, rice farmers use production factors is not efficient [1] among others, rely on inorganic fertilizers with very high doses. That tendency causesvarious negative impact of using inorganic fertilizers, ranging from damage to the ecosystem, loss of soil fertility to health problems $[2,3]$. Organic fertilizer refers to materials used as fertilizer that occur regularly in nature, usually as a by product or end product of a naturally occurring process. Organic fertilizers are sustained sources of nutrients due to slow release during decomposition [4]. Therefore, the use of organic fertilizer is encouraged to overcome these problems [5]

Organic fertilizer is fertilizer derived from dead plants, animal dung or animal parts, and other organic waste. It has been through an engineering process and can be enriched with

*Correspondingauthor: rohbudi68@yahoo.com 
minerals and microbes. Organic fertilizer is useful for increasing nutrient content and soil organic matter, and improving physical, chemical, and biological soil characteristics [2]. Organic fertilizers produced through the process of drying, cooking, composting [6], chopping, grinding and fermenting [7], or other method.

Nutrient composition in organic fertilizer is very dependent on the source of origin of the basic ingredients. The sources of organic fertilizer were from agricultural and non-agricultural activities. The source from agriculture activities can be in the form of crop residues and livestock manure, while from non-agriculture can come from municipal organic waste, industrial waste, and so on.

Organic fertilizer technology is growing rapidly. The use of Granules Organic Fertilizer (GOF) in rice plants is expected to improve land conditions, technically easy to apply, and improve the growth and yield of rice plants. Organic fertilizer senhance the natural soil processes, which have long-termeffects on soil fertility [4].

The purpose of this study was to determine the effectiveness of GOF on the growth and yield of rice plants.

\section{Research methods}

The study was conducted in the Mojosari research station, Mojokerto, East Java, Indonesia from February 2017 to August 2017. The materials used in this study included: Inpari 30 variety of rice seeds, GOF, comparative organic fertilizer (Petroganik), Urea fertilizer, and Phonska fertilizer. The equipment used were a tillage machine (hand tractor), hoe, and equipment for observation and harvest.

A previous study showed that soil at the Mojosari research station had a Neutral Acidity $(\mathrm{pH})$. Organic matter content and macronutrients were low, but $\mathrm{P}$ and $\mathrm{Ca}$ were high.

The experimental design used was a Randomized Block Design (RBD). The treatment of organic fertilizer was arranged in six levels of organic fertilizer $\left(1000 \mathrm{~kg} \mathrm{ha} \mathrm{ha}^{-1}\right.$, $2000 \mathrm{~kg} \mathrm{ha}^{-1}, 3000 \mathrm{~kg} \mathrm{ha}^{-1}, 4000 \mathrm{~kg} \mathrm{ha}^{-1}, 5000 \mathrm{~kg} \mathrm{ha}^{-1}$, and $6000 \mathrm{~kg} \mathrm{ha}^{-1}$ ). Each of the level was combined with $300 \mathrm{~kg}$ of Urea and $300 \mathrm{~kg}$ of Phonska. As a comparison, it used one standard fertilizing treatment (Petroganik $2000 \mathrm{~kg} \mathrm{ha}^{-1}+$ Urea $300 \mathrm{~kg} \mathrm{ha}^{-1}$ and Phonska $300 \mathrm{~kg} \mathrm{ha}{ }^{-1}$ ) and one treatment without fertilization as a control. All treatments were repeated three times. Data were analyzed using ANOVA. Further tests were carried out using the Least Significant Difference Test (LSD) at the $5 \%$ level.

RAE (Relative Agronomic Effectiveness) was used to compare the effectiveness of each organic fertilizer against standard fertilizer. RAE is the ratio between the increase in yield due to the use of a fertilizer with the increase in yield with the use of a standard fertilizer multiplied by 100 [2], with the Formula (1):

$$
\mathrm{RAE}=\frac{\text { Yield of tested fertilizer }- \text { results on control }}{\text { Standard fertilizer yields }- \text { results on control }} \times 100 \%
$$

To find out the feasibility level of rice farming, the simplest financial analysis approach using $\mathrm{R} / \mathrm{C}$ was the ratio between revenue and cost. If $\mathrm{R} / \mathrm{C}>1$, meansthe business is feasible to be continued, and if $\mathrm{R} / \mathrm{C}<1$ then the business is not feasible/inefficient to be continued and $\mathrm{R} / \mathrm{C}=1$ means the farming carried outreaches breakeven. Comparison between the amount of revenue and cost using the Formula (2) [8], as follows:

$$
\mathrm{R} / \mathrm{C} \text { ratio }=\mathrm{TR} / \mathrm{TC}
$$

$\mathrm{TR}=$ Total Revenue

$\mathrm{TC}=$ Total Cost 


\section{Results and discussions}

Table 1 showed that at the age of 21 dap (day after plantation), the highest average plant height was shown in the treatment of $3000 \mathrm{~kg} \mathrm{ha}^{-1} \mathrm{GOF}$, but not significantly different with the treatment of $2000 \mathrm{~kg} \mathrm{ha}^{-1}, 4000 \mathrm{~kg} \mathrm{ha}^{-1}$ and $6000 \mathrm{~kg} \mathrm{ha}^{-1} \mathrm{GOF}$. At $70 \mathrm{dap}$, the highest average was shown in the treatment of $3000 \mathrm{~kg} \mathrm{ha}^{-1} \mathrm{GOF}$ with average value of 89.4 but not significantly different from the standard treatment, $2000 \mathrm{~kg} \mathrm{ha}^{-1}, 4000 \mathrm{~kg} \mathrm{ha}^{-1}$, $5000 \mathrm{~kg} \mathrm{ha}^{-1}$, and $6000 \mathrm{~kg} \mathrm{ha}^{-1} \mathrm{GOF}$. At the age of 35 and 56 dap the highest average was shown in the treatment of $4000 \mathrm{~kg} \mathrm{ha}^{-1} \mathrm{GOF}$. At 56 dap, the addition of GOF organic fertilizer to $6000 \mathrm{~kg} \mathrm{ha}^{-1}$ did not show any significant difference. This indicated that the nutrients contained in the treated organic fertilizer did not affect the height of the rice plant because the GOF cannot be directly utilized by the plant and also the amount of nutrients contained in the GOF was low. According to [9], granules fertilizer or pellets can prevents the occurrence of segretion, prevents an overdose of plants against shedding sudden nutrition. The results of this study are different from [10] that plant height were significantly increased in all the treatments over control.

Table 1. Effect of GOF on plant height

\begin{tabular}{|c|c|c|c|c|}
\hline \multirow{2}{*}{ Treatment $\left(\mathrm{kg} \mathrm{ha}^{-1}\right)$} & \multicolumn{4}{|c|}{ Plant height $(\mathrm{cm})$} \\
\cline { 2 - 5 } & $21 \mathrm{dap}$ & $35 \mathrm{dap}$ & $56 \mathrm{dap}$ & $70 \mathrm{dap}$ \\
\hline Control (without fertilizer) & $46.9 \mathrm{c}$ & $54.9 \mathrm{c}$ & $55.9 \mathrm{~b}$ & $77.2 \mathrm{c}$ \\
\hline $\begin{array}{c}\text { Standart (2 000 Petroganik + 300 Urea +300 } \\
\text { Phonska) }\end{array}$ & $51.5 \mathrm{~b}$ & $57.2 \mathrm{bc}$ & $69.7 \mathrm{a}$ & $85.3 \mathrm{ab}$ \\
\hline$(1000 \mathrm{GOF}+300$ Urea + 300 Phonska) & $52.2 \mathrm{~b}$ & $56.9 \mathrm{bc}$ & $68.5 \mathrm{a}$ & $80.7 \mathrm{bc}$ \\
\hline (2000 GOF + 300 Urea + 300 Phonska) & $53.5 \mathrm{ab}$ & $58.5 \mathrm{bc}$ & $70.5 \mathrm{a}$ & $88.0 \mathrm{a}$ \\
\hline (3000 GOF + 300 Urea + 300 Phonska) & $57.7 \mathrm{a}$ & $61.3 \mathrm{ab}$ & $69.0 \mathrm{a}$ & $89.4 \mathrm{a}$ \\
\hline (4000 GOF + 300 Urea + 300 Phonska) & $54.7 \mathrm{ab}$ & $64.5 \mathrm{a}$ & $71.7 \mathrm{a}$ & $88.0 \mathrm{a}$ \\
\hline (5000 GOF + 300 Urea + 300 Phonska) & $52.9 \mathrm{~b}$ & $59.9 \mathrm{ab}$ & $69.6 \mathrm{a}$ & $87.7 \mathrm{a}$ \\
\hline (6000 GOF + 300 Urea + 300 Phonska) & $55.1 \mathrm{ab}$ & $59.7 \mathrm{abc}$ & $70.5 \mathrm{a}$ & $88.0 \mathrm{a}$ \\
\hline Anova & $*$ & $*$ & $*$ & $*$ \\
\hline CV (\%) & 4.62 & 4.78 & 5.22 & 3.15 \\
\hline LSD 5 \% & 4.29 & 4.95 & 6.23 & 4.72 \\
\hline
\end{tabular}

Note: GOF $=$ Granular Organic Fertilizer, dap = Day After Planting

The number followed by the same letter in one column was not significantly different based on the LSD test of $5 \%$

* = Significantly different at $5 \%$

Table 2 showed that the highest average number of tillers at the age of 21 dap was shown in the dose of $4000 \mathrm{~kg} \mathrm{ha}^{-1} \mathrm{GOF}$ with an average value of 19.6. At the age of 35 dap, the highest average number of tillers was at the dose $5000 \mathrm{~kg} \mathrm{ha}^{-1} \mathrm{GOF}$, but not significantly different with the treatment of $3000 \mathrm{~kg} \mathrm{ha}^{-1} \mathrm{GOF}$. At the age of 56 and $70 \mathrm{dap}$, the highest number of tillers was obtained in the treatment of $5000 \mathrm{~kg} \mathrm{ha}^{-1} \mathrm{GOF}$. At the age of $70 \mathrm{dap}$, the number of tillers in the treatment was not significantly different with the treatment of $4000 \mathrm{~kg} \mathrm{ha}^{-1} \mathrm{GOF}, 6000 \mathrm{~kg} \mathrm{ha}^{-1} \mathrm{GOF}$. 
Table 2. Effect of GOF on number of tillers

\begin{tabular}{|c|c|c|c|c|}
\hline \multirow{2}{*}{ Treatment $\left(\mathrm{kg} \mathrm{ha}^{-1}\right)$} & \multicolumn{4}{|c|}{ Number of tillers } \\
\cline { 2 - 5 } & $21 \mathrm{dap}$ & $35 \mathrm{dap}$ & $56 \mathrm{dap}$ & $70 \mathrm{dap}$ \\
\hline Control (without fertilizer) & $11.3 \mathrm{e}$ & $13.3 \mathrm{e}$ & $13.7 \mathrm{e}$ & $13.9 \mathrm{e}$ \\
\hline $\begin{array}{c}\text { Standart (2 000 Petroganik + 300 Urea + 300 } \\
\text { Phonska) }\end{array}$ & $15 \mathrm{~cd}$ & $15.0 \mathrm{~d}$ & $17.8 \mathrm{~d}$ & $17.9 \mathrm{~d}$ \\
\hline (1 000 GOF + 300 Urea + 300 Phonska) & $14.1 \mathrm{~d}$ & $16.2 \mathrm{c}$ & $19.5 \mathrm{~cd}$ & $19.5 \mathrm{~cd}$ \\
\hline (2000 GOF + 300 Urea + 300 Phonska) & $17.3 \mathrm{~b}$ & $19.6 \mathrm{~b}$ & $21.0 \mathrm{bc}$ & $21.4 \mathrm{bc}$ \\
\hline (3000 GOF + 300 Urea + 300 Phonska) & $17.0 \mathrm{~b}$ & $20.7 \mathrm{ab}$ & $21.0 \mathrm{bc}$ & $23.1 \mathrm{ab}$ \\
\hline (4000 GOF + 300 Urea + 300 Phonska) & $19.6 \mathrm{a}$ & $19.6 \mathrm{~b}$ & $21.4 \mathrm{~b}$ & $23.5 \mathrm{a}$ \\
\hline (5000 GOF + 300 Urea + 300 Phonska) & $16.3 \mathrm{bc}$ & $21.0 \mathrm{a}$ & $24.2 \mathrm{a}$ & $24.2 \mathrm{a}$ \\
\hline (6000 GOF + 300 Urea + 300 Phonska) & $15.5 \mathrm{bc}$ & $20.9 \mathrm{a}$ & $22.0 \mathrm{~b}$ & $23.2 \mathrm{ab}$ \\
\hline Anova & $* *$ & $* *$ & $* *$ & $* *$ \\
\hline CV (\%) & 7.12 & 3.68 & 5.12 & 5.84 \\
\hline LSD 5\% & 1.96 & 3.11 & 1.80 & 2.13 \\
\hline
\end{tabular}

Note: $\mathrm{GOF}=$ Granular Organic Fertilizer, dap $=$ Day After Planting

The number followed by the same letter in one column was not significantly different based on the LSD test of $5 \%$

$*$ = Significantly different at $5 \%$

The number of panicles per clump ranged from 7.9 to 14.6 panicles. The lowest number of panicles was found in the treatment without fertilization while the highest was achieved in the treatment of $3000 \mathrm{~kg} \mathrm{ha}^{-1} \mathrm{GOF}$, but not significantly different with the treatments of $2000 \mathrm{~kg} \mathrm{ha}^{-1} \mathrm{GOF}, 4000 \mathrm{~kg} \mathrm{ha}^{-1} \mathrm{GOF}, 5000 \mathrm{~kg} \mathrm{ha}^{-1} \mathrm{GOF}$, and $6000 \mathrm{~kg} \mathrm{ha}^{-1} \mathrm{GOF}$ (Table 3).

The number of filled grains per panicle ranged from 86.6 to 172.0. Filled Grain panicle $^{-1}$ is lowest in the treatment without fertilization, while the highest is in the treatment of $5000 \mathrm{~kg} \mathrm{ha}^{-1} \mathrm{GOF}$, which is not significantly different from the number of filled grain in the treatment of $3000 \mathrm{~kg} \mathrm{ha}^{-1} \mathrm{GOF}, 4000 \mathrm{~kg} \mathrm{ha}^{-1} \mathrm{GOF}$ and $6000 \mathrm{~kg} \mathrm{ha}^{-1} \mathrm{GOF}$ (Table 3).

The number of empty grains panicle ${ }^{-1}$ ranges from 9.2 to 22.0 . The highest number of empty grain is found in the highest fertilizer treatment (6 $\left.000 \mathrm{~kg} \mathrm{ha}^{-1} \mathrm{GOF}\right)$. While the lowest number of empty grains was found in the treatment of $2000 \mathrm{~kg} \mathrm{ha}^{-1} \mathrm{GOF}$, which was not significantly different from the treatment of $1000 \mathrm{~kg} \mathrm{ha}^{-1}$ GOF (Table 3).

Table 3. Effect of GOF on number of panicles per clump, number of filled and empty grain panicle ${ }^{-1}$

\begin{tabular}{|c|c|c|c|}
\hline \multirow{2}{*}{ Treatment $\left(\mathrm{kg} \mathrm{ha}^{-1}\right)$} & \multirow{2}{*}{$\begin{array}{c}\text { Number of } \\
\text { panicles } \\
\text { clump }^{-1}\end{array}$} & \multicolumn{2}{|c|}{$\begin{array}{c}\text { Number of grain per } \\
\text { panicles }\end{array}$} \\
\cline { 3 - 4 } & Filled & Empty \\
\hline Control (without fertilizer) & $7.9 \mathrm{~d}$ & $86.6 \mathrm{c}$ & $11.7 \mathrm{~d}$ \\
\hline Standart (2 000 Petroganik + 300 Urea + 300 Phonska) & $12.5 \mathrm{bc}$ & $124.8 \mathrm{~b}$ & $11.2 \mathrm{~d}$ \\
\hline (1000 GOF + 300 Urea + 300 Phonska) & $11.2 \mathrm{c}$ & $121.7 \mathrm{bc}$ & $11.0 \mathrm{de}$ \\
\hline (2000 GOF + 300 Urea + 300 Phonska) & $13.3 \mathrm{ab}$ & $125.3 \mathrm{~b}$ & $9.2 \mathrm{e}$ \\
\hline (3000 GOF + 300 Urea + 300 Phonska) & $14.6 \mathrm{a}$ & $152.9 \mathrm{ab}$ & $12.3 \mathrm{~d}$ \\
\hline (4000 GOF + 300 Urea + 300 Phonska) & $14.4 \mathrm{a}$ & $148.8 \mathrm{ab}$ & $14.8 \mathrm{c}$ \\
\hline (5000 GOF + 300 Urea + 300 Phonska) & $14.5 \mathrm{a}$ & $172.0 \mathrm{a}$ & $18.1 \mathrm{~b}$ \\
\hline (6000 GOF + 300 Urea + 300 Phonska) & $13.3 \mathrm{ab}$ & $154.8 \mathrm{ab}$ & $22.0 \mathrm{a}$ \\
\hline Anova & $* *$ & $* *$ & $* *$ \\
\hline CV (\%) & 7.20 & 14.44 & 7.34 \\
\hline LSD 5 \% & 1.61 & 34.39 & 1.77 \\
\hline
\end{tabular}

Note: GOF $=$ Granular Organic Fertilizer

The number followed by the same letter in one column is not significantly different based on the LSD test of $5 \%$

** = Significantly different at $1 \%$ 
Table 4 showed that the weight of 1000 seeds no significant difference among treatments. It showed that the GOF and petroganik did not affect the weight of seeds. For variable harvested driedgrain yield, the treatments showed very significant differences. Harvested dried grain yield ranged from $3.57 \mathrm{tha}^{-1}$ to $7.21 \mathrm{tha}^{-1}$.

The lowest harvested dried grain yield was found in the treatment without fertilization, while the highest was achieved in the treatment of 3000 GOF but no significant difference with the 4000 GOF and 5000 GOF (Table 4).

This research showed that the increase in the amount of GOF was not followed by the rate of increase in production. The reasons were, i) GOF utilization had the same effect as petroganik fertilizer, ii) In production parameters, GOF and petroganik gave the same advantages effect. Besides nutrients as a determinant of productivity, rice varieties also determined the yields.

Organic fertilizer is useful for improving the texture and structure of the soil, there by accelerating the process of absorption of nutrients by plants. Improved soil structure, a season-long supply of nutrients, and an increased water-holding capacity are some of the benefits of using organic fertilizers $[11,6]$. The absorption of nutrients following the needs of plants havea positive impact on plant growth and yield. The generative phase begins with the emergence of rice panicles, followed by the process of fruit set and seed set. Environmental conditions and the availability of nutrients is very influential in the filling phase of rice grains. The different environmental conditions results in the difference in temperature and radiation which ultimately affected grain yield formation in rice $[12,13]$. Therefore, providing the right type of nutrition and the right amount can increase rice yield and productivity.

Table 4. Effect of GOF on 1000 seed weights and harvested dried grain yield

\begin{tabular}{|c|c|c|}
\hline Treatment $\left(\mathrm{kg} \mathrm{ha}^{-1}\right)$ & $\begin{array}{l}1000 \text { seed } \\
\text { weights }(\mathrm{g})\end{array}$ & $\begin{array}{c}\text { Harvested } \\
\text { dried grain } \\
\text { yield }\left(\mathrm{t} \mathrm{ha}^{-1}\right)\end{array}$ \\
\hline Control (without fertilizer) & $26.1 \mathrm{ab}$ & $3.57 \mathrm{e}$ \\
\hline Standart $(2000$ Petroganik +300 Urea +300 Phonska $)$ & $25.9 \mathrm{ab}$ & $6.71 \mathrm{~cd}$ \\
\hline (1 000 GOF +300 Urea +300 Phonska $)$ & $25.9 \mathrm{ab}$ & $6.65 \mathrm{~d}$ \\
\hline (2 000 GOF + 300 Urea + 300 Phonska) & $26.8 \mathrm{a}$ & $6.71 \mathrm{~cd}$ \\
\hline (3000 GOF + 300 Urea + 300 Phonska) & $25.9 \mathrm{ab}$ & $7.21 \mathrm{a}$ \\
\hline (4000 GOF + 300 Urea + 300 Phonska) & $25.7 \mathrm{~b}$ & $7.11 \mathrm{ab}$ \\
\hline (5 000 GOF +300 Urea +300 Phonska) & $26.17 \mathrm{ab}$ & $7.15 \mathrm{a}$ \\
\hline$(6000$ GOF +300 Urea +300 Phonska) & $25.6 \mathrm{~b}$ & $6.89 \mathrm{bc}$ \\
\hline Anova & ns & $* *$ \\
\hline $\mathrm{CV}(\%)$ & 2.16 & 2.05 \\
\hline LSD 5\% & 0.98 & 0.23 \\
\hline
\end{tabular}

Note: GOF $=$ Granular Organic Fertilizer

The number followed by the same letter in one column is not significantly different based on the LSD test of $5 \%$

ns $=$ Not significantly different

$* *=$ Significantly different at $1 \%$

The results of RAE analysis showed that the treatment GOF $1000 \mathrm{~kg}$ had not been able to match the treatment Standart, because it had the RAE value of $98 \%$, which means that treatment GOF $1000 \mathrm{~kg}$ was not feasible to apply. While the treatment GOF $3000 \mathrm{~kg}$ was effective based on agronomic with the RAE value was $116 \%$. This means that the dose of the fertilizer can increase yield by 1.16 times (Table 5 ). 
Table 5. RAE value of GOF treatments on rice plants

\begin{tabular}{|c|c|}
\hline Treatments $\left(\mathrm{kg} \mathrm{ha}^{-1}\right)$ & RAE $(\%)$ \\
\hline Control (without fertilizer) & - \\
\hline Standart (2 000 Petroganik +300 Urea +300 Phonska) & - \\
\hline$(1000$ GOF +300 Urea + 300 Phonska) & 98 \\
\hline$(2000$ GOF +300 Urea +300 Phonska) & 100 \\
\hline (3000 GOF + 300 Urea + 300 Phonska) & 116 \\
\hline (4 000 GOF + 300 Urea + 300 Phonska) & 113 \\
\hline$(5000$ GOF + 300 Urea + 300 Phonska $)$ & 114 \\
\hline$(6000$ GOF +300 Urea +300 Phonska) & 106 \\
\hline
\end{tabular}

Table 6 showed the results of the economic feasibility analysis of each treatment. The revenue rate is the result of multiplying the selling price of grain with grain yield. Based on the selling price of grain at the time of the study was IDR $3500 \mathrm{~kg}^{-1}$, then the average income of farmers ranged from ID R12 495000 to IDR 25235000 . The lowest income was shown in treatment without fertilizer while the highest was in treatment GOF $3000 \mathrm{~kg}$.

Table 6. Recapitulation of simple economicanalysis of GOF treatment on rice

\begin{tabular}{|c|c|c|c|c|}
\hline Treatments $\left(\mathrm{kg} \mathrm{ha}^{-1}\right)$ & $\begin{array}{c}\text { Income } \\
\text { (x IDR } \\
1000)\end{array}$ & $\begin{array}{c}\text { Cost } \\
(\mathrm{x} \text { IDR } \\
1000)\end{array}$ & $\begin{array}{c}\text { Benefit } \\
(\mathrm{x} \text { IDR } \\
1000)\end{array}$ & R/C \\
\hline Control (without fertilizer) & 12495 & 13480 & $(985)$ & 0.93 \\
\hline $\begin{array}{c}\text { Standart (2 000 Petroganik + 300 Urea + } \\
\text { 300 Phonska) }\end{array}$ & 23485 & 15740 & 7745 & 1.49 \\
\hline (1 000 GOF + 300 Urea + 300 Phonska) & 23275 & 16640 & 6635 & 1.40 \\
\hline (2000 GOF + 300 Urea + 300 Phonska) & 23485 & 18540 & 4945 & 1.27 \\
\hline (3000 GOF + 300 Urea + 300 Phonska) & 25235 & 20440 & 4795 & 1.23 \\
\hline (4000 GOF + 300 Urea + 300 Phonska) & 24885 & 22340 & 2545 & 1.11 \\
\hline (5000 GOF +300 Urea + 300 Phonska) & 24885 & 24240 & 785 & 1.03 \\
\hline (6000 GOF + 300 Urea + 300 Phonska) & 24115 & 26140 & $(2025)$ & 0.92 \\
\hline
\end{tabular}

Description of price per $\mathrm{kg}$ :

Grain yield $=$ IDR 3 500, Urea $=$ IDR 1 900, Phonska $=$ IDR 2 300, Petroganik $=$ IDR 500, GOF = IDR 1900.

Farming costs consist of land rent, labor costs, seeds, organic fertilizer (Petroganik), GOF fertilizer, Phonska, Urea, fungicide, and insecticide in one planting season. The lowest total cost was shown in treatment without fertilizer of IDR 13480000 and the highest cost for treatment GOF $6000 \mathrm{~kg}$ of IDR 26140000 (Table 6).

The benefit is the difference between revenue and costs incurred. Table 6 showed that the GOF treatment reached the highest profit was in treatment GOF $1000 \mathrm{~kg} \mathrm{ha}^{-1}$ of IDR 6635000 with an R/C ratio of 1.40 but still below the standard treatment (Table 6). Increased use of GOF $5000 \mathrm{~kg} \mathrm{ha}^{-1}$ resulted in reduced profits. On the use of GOF $6000 \mathrm{~kg} \mathrm{ha}^{-1}$ GOF suffered a loss of IDR 2025000 with an R/C ratio of 0.92 . This showed that the increase in the use of GOF is not proportional to the rate of increase in production and results in reduced profits.

\section{Conclusions}

Granule Organic Fertilizer (GOF) significantly affected the growth and yield of rice plants. The use of GOF $3000 \mathrm{~kg}+300 \mathrm{~kg}$ Urea $+300 \mathrm{~kg}$ Phonska ha ${ }^{-1}$ had the highest grain yield 
(7.21 $\left.\mathrm{t} \mathrm{ha}^{-1}\right)$ with an RAE value of $116 \%$ or an increase of $0.5 \mathrm{t}(7.45 \%)$ compared to grain yield at the use of standard fertilizers $\left(2000 \mathrm{~kg} \mathrm{ha}^{-1}\right.$ Petroganic $+300 \mathrm{~kg} \mathrm{ha}^{-1}$ Urea + $300 \mathrm{~kg} \mathrm{ha}^{-1}$ Phonska). The highest profit rate for using GOF $1000 \mathrm{~kg} \mathrm{ha}^{-1}+300 \mathrm{~kg} \mathrm{ha}^{-1}$ Urea $+300 \mathrm{~kg} \mathrm{ha}^{-1}$ Phonska was IDR 6635000 with an $\mathrm{R} / \mathrm{C}$ ratio of 1.4.

\section{References}

1. R. Budiono, P.G. Adinurani. Efficiency analysis of production factors utilization in upland rice farming. KnE Life Sciences: 180-187(2017).

https://doi.org/10.18502/kls.v3i5.991

2. S. Savci. APCBEE Procedia. 1:287-292(2012). https://doi.org/10.1016/j.apcbee.2012.03.047

3. R Budiono, P.G. Adinurani, P. Soni. IOP Conf. Series: Earth and Environmental Science 293 (2019) 012034. p.10. https://doi.org/10.1088/1755-1315/293/1/012034

4. R. Singh. Organic fertilizers types, production and environmental impact. Nova Science Publisher, New York (2012). p. 1-261.

https://www.researchgate.net/publication/274896698_Organic_Fertilizers_Types_Produ ction_and_Environmental_Impact

5. E.D. Purbajanti, F. Kusmiyati, W. Slamet, P.G. Adinurani. AIP Conference Proceedings, 1755,130013:1-4(2016). https://doi.org/10.1063/1.4958557

6. D. Dadi, G. Daba, A. Beyene, P. Luis, B.V. der Bruggen. Int J Recycl Org Waste Agric. 8:263-277(2019). https://doi.org/10.1007/s40093-019-0256-8

7. M.A.H. Chontal, C.J.L. Collado, N.R. Orozco, J.V. Velasco, A.L. Gabriel, G.L. Romero. Int J Recycl Org Waste Agric. 8:309-315(2019).

https://doi.org/10.1007/s40093-019-0248-8

8. D.K.S. Swastika. Jurnal Pengkajian dan Pengembangan Teknologi Pertanian. 7,1: 90-103(2004). [in Bahasa Indonesia].

http://103.213.119.214/index.php/jpengkajian/article/download/1503/1282

9. N.W.A. Utari, T. Tamrin, S. Triyono. Jurnal Teknik Pertanian Lampung. 3,3: 267-274(2015). [in Bahasa Indonesia].

https://docs.google.com/viewerng/viewer?url=http://jurnal.fp.unila.ac.id/index.php/JTP/ article/viewFile/666/608

10. M. Siavoshi, A. Nasiri, S.L. Laware. Journal of Agricultural Science. 3,3: 217-224(2011). https://doi.org/10.5539/jas.v3n3p217

11. G. Silva. Michigan State University Extension. (2018).

https://scholar.google.co.id/scholar?hl=id\&as_sdt=0\%2C $5 \& \mathrm{q}=$ What + organic + fertilizers + mean + to + plants + and + soil\&btnG $=$ https://www.canr.msu.edu/news/what_organic_fertilizers_mean_to_plants_and_soil

12. Z. Mo, W. Li, S. Pan, T.L. Fitzgerald, F. Xiao, Y. Tang, et al. Rice. 8,1:9(2015). https://doi.org/10.1186/s12284-015-0040-y

13. S. Li, H. Jiang, J. Wang, Y. Wang, S. Pan, H. Tian, et. al. Scientific Reports.

9:10618(2019). https://doi.org/10.1038/s41598-019-47031-9 